\title{
5. När elever i spanska söker efter specifik information på internet
}

Lisa Källermark Haya

Det var verkligen roligt, nyttigt och lärorikt att få jobba $i$ grupp och i tema med autentiska texter på nätet. Men det tog väldigt lång tid för att lära sig ganska lite på spanska.

Citatet kommer från en flicka i årskurs två på gymnasiet som intervjuas om vad hon upplevde som viktigt efter att hon, som en del av ett temaarbete i spanska 4, ombetts söka efter specifik information på spanskspråkiga webbsidor. Det illustrerar en sammanfattning av den licentiatavhandling som det här kapitlet baserar sig på (Källermark Haya, 20 I5a). I studien undersöktes i detalj hur två elevgrupper navigerade sig igenom sitt första arbetspass i ett längre temaarbete om Latinamerika. Det här kapitlet handlar å ena sidan om vilka val som eleverna uttryckte att de gjorde under lektionspasset, hur de faktiskt arbetade och vilka resurser de använde sig av under denna lektion. Å andra sidan handlar texten om vilka val och resurser läraren nämnde som väsentliga för eleverna i deras arbete. Resultaten visar att det finns en diskrepans mellan det elever och lärare uttryckte när det gäller flera aspekter av dessa val och resurser. Kapitlet avslutas med en diskussion som fokuserar på skillnaderna mellan elevers och lärares aktivitetssystem och vad dessa skulle kunna innebära för språkundervisningen.

\section{Kollaborativt arbete med datorn som verktyg i språkundervisningen - vad säger forskningen?}

År 20 I 4 hade 200 av 290 svenska kommuner infört så kallade I-till-I-lösningar där varje elev försetts med ett eget digitalt verktyg

Hur du refererar till det här kapitlet:

Källermark Haya, L. (202I). När elever i spanska söker efter specifik information på internet. I Bardel, C. et al. (Red.). Forskarskolan FRAM - lärare forskar $i$ de främmande språkens didaktik (s. I05-I23). Stockholm: Stockholm University Press. DOI: https://doi.org/Io.I6993/bbg.f. License: CC-BY 4.0. 
(till exempel surfplatta, telefon eller dator) för sitt lärande (Grönlund, 20I4). Det finns förhållandevis få studier som undersöker vad svenska elever egentligen använder digitala verktyg till i sin språkinlärning. En spansk studie visade 2006 att eleverna mest använde sina datorer som skrivverktyg och för att söka information på internet (Vaca Uribe \& Hernández, 2006). Patrik Svensson skriver bland annat om språkinlärning som något som kan ske gemensamt och i utforskande möten "i förhållande till, tillsammans och genom andra" (Svensson, 2008, s. 58). Några författare visar att språkinlärningen kan stödjas när elever arbetar i grupp och skapar något tillsammans (Diaz, 20I2; Svensson, 2008) och vissa undersökningar ger vid handen att just användningen av digitala verktyg kan uppmuntra till detta kollaborativa sätt att lära sig på (Patterson, 2000). I de fall lärande sker genom att människor kommunicerar med varandra (Lantolf \& Thorne, 2006) så spelar rimligen också formen för deras kommunikation stor roll för vad det är de lär sig.

Fredholm (2015) undersökte elever som i sina språkstudier använde datorn som just skrivverktyg, men det var det andra stora användningsområdet, att söka information på nätet, som fångade mitt intresse. Något som bidrog till det var det faktum att de slags texter eleverna läser på internet möjligen innebär en helt egen typ av läsning om man jämför med läsning i textböcker (Patterson, 2000). Jag ville undersöka vad språkeleverna i en liten grupp egentligen använde sina datorer till när de gick iväg till ett grupprum för att arbeta kring ett tema där de förväntades söka efter information på webben.

\section{Internet i skolan, språkundervisningen och hur vi läser vi på internet}

Även om ungdomar i Sverige generellt använder och har tillgång till digitala verktyg så finns en stor ojämlikhet i deras kunskaper om hur dessa kan användas. Kunskapsskillnaderna mellan olika skolor förstärker denna ojämlikhet (Samuelsson, 20I4). Trots att användningen av digitala hjälpmedel ökar - i alla ämnen - upplever eleverna heller inte att deras kunskaper om dem förbättras, och deras lärare uppger ett fortsatt stort behov av kompetensutveckling (Skolverket, 20I6). När det gäller språkinlärning visade Vigmo (20I0) hur elevernas lingvistiska fokus kunde komma att 
styras av digitala media och att olika förmågor (tala, läsa, skriva) blandades. Användningen av dessa media kunde även strukturera hur elevernas aktiviteter utvecklar sig och vad som blev huvudfokus. Till exempel blev språkinlärningen lidande när tekniken inte fungerade. De elevgrupper som deltog i hennes forskning vände sig hellre till varandra än till läraren om de behövde hjälp. Vigmo betonar att språkeleven med digitala verktyg blir både språklig producent och konsument på samma gång. Hon menar att lärarens uppgift då blir att kunna designa aktiviteten så att språkinlärningen inte underordnas de tekniska villkoren.

Det slags text som eleverna möter på nätet är annorlunda än den för språkinlärningen tillrättalagda stycketexten i textböcker. Förenklat så handlar ju läsning på internet om sites i stället för sidor - till exempel bestämmer eleverna själva genom sina klick var och hur läsvägen - texten - börjar och slutar, eller om de till exempel väljer att surfa via bildbanker. I stället för att följa en av läraren eller textboksförfattaren på förhand bestämd läsväg så blir eleven på det sättet själv i högre grad en medproducent av sina läromedia (Kress, 2009, s. 38 ).

Marc Prensky skrev 200I en artikel där han myntade begreppen digital immigrants och digital natives (Prensky, 200I). Han menade att de som fötts in i en värld med digitala hjälpmedel och de som inte gjort det närmar sig digitala praktiker på markant olika sätt. De 'infödda' (natives), menar Prensky, ser digitala hjälpmedel som helt naturliga och närmar sig dem på ett okomplicerat sätt där de kan skörda frukterna av de möjligheter den digitala världen erbjuder. 'Immigranterna' (immigrants), däremot, stöter ofta på problem och behöver hela tiden översätta sina vanor från icke-digitala praktiker till för dem nya digitala miljöer. Detta skulle kunna innebära att digitala infödda och immigranter för med sig sina respektive vardagspraktiker in på internet och därför läser webbtexter på olika sätt (Selwyn, 20I0, 20II).

Ett exempel skulle kunna vara att när ungdomar läser på nätet läser de till exempel inte från vänster till höger utan scrollar ned och upp, blandar olika media i högre grad än äldre läsare, använder fler olika element som till exempel ljud/bild/film och rör sig mellan fler simultana flikar. Ofta går läsning vid informationssökning dessutom jämförelsevis snabbt: ett exempel är min pilotundersökning som undersökte elever i spanska 4 när de sökte information 
på spanska. Där konstaterades att den längsta tiden som spenderades på en spansk sida utan att eleven rörde sig mellan olika dokument eller webbsidor, och den eftersökta informationen hittades, var 33 sekunder (Källermark Haya, 20 I 5 b, s. I 54). För språklärare kan detta resultat väcka frågor om ytlig läsning eller djupläsning och om vad eleverna egentligen lär sig språkmässigt av respektive typ av läsning.

Användningen av internet och digitala verktyg är central i hur eleven organiserar och orienterar sig i sin lärprocess (Conole, 2008). Benyamine (2008) fann att elever som söker information på nätet ofta startar sin informationssökning med stora mängder information som de sällan kan relatera till på ett personligt plan, snarare än att utgå från något de själva konkretiserat att de vill arbeta vidare med. Han menar att detta medför en risk att digitala medier gör kunskap till något abstrakt i stället för något konkret som är lätt att relatera till.

Om lärare och elever har olika syn på internets roll när det används för till exempel informationssökning i språkinlärningen, riskerar de att inte delta i samma aktivitetssystem, en term tagen från Engeström (2000). Deltar lärare och elever i olika aktivitetssystem ökar risken för missförstånd kring vad det är egentligen aktiviteten handlar om. I ett aktivitetssystem ingår förenklat sett subjektet för en viss aktivitet, samt objekt och mål. I ett fiktivt exempel skulle lärarens (subjektet i det första aktivitetssystemet) mål kunna vara att eleverna (objekt) ska få öva sig på att läsa autentiskt språk, till exempel ordförrådet i köp- och sälj annons för hundar. I ett annat simultant aktivitetssystem skulle eleverna kunna vara subjekt, med målet att snabbt hitta den av eleven eftersökta informationen (eller den information som elever tolkar att läraren vill att de ska hitta), till exempel genom att bildgoogla på det spanska ordet perros för att kunna presentera för kamraterna vilken sorts hundar som är sötast. Objektet skulle där kunna utgöras av ett bildmaterial.

\section{Undersökningens syfte och mål}

Syftet med min licentiatavhandling var att med ett sociokulturellt perspektiv på språkinlärning (se t ex Lantolf \& Thorne, 2006), 
undersöka de val och handlingar som gymnasieelever i spanska och deras lärare använde sig av när eleverna arbetade med informationssökning inom ramen för spanskstudierna, och där eleverna, för att genomföra en del av uppgiften, förväntades läsa websidor skrivna på spanska för spansktalande läsare. Forskningsfrågan som ställdes löd: Vilka val, handlingar och muntliga återgivanden gör elever och lärare i arbetet beskrivet ovan? Jag ville dessutom diskutera vad deltagarnas svar kunde ha för konsekvenser för språkinlärningen. En lärare i spanska (Sara) och sex av hennes elever i spanska 4 på gymnasiet, accepterade att delta i studien.

\section{Elevernas uppgift}

Den uppgift som ligger till grund för undersökningen planerades av elevernas spansklärare tillsammans med dennas ämneskollegor under tre möten. Läraren hade över 20 år i yrket och hade arbetat med lärares fortbildning i IT på regional nivå. Kollegorna planerade vad som skulle hända varje vecka för att kursplanen i spanska 4 skulle följas och elevernas kunskaper sedan redovisas. Lärarna ville under perioden fokusera på det innehåll och de kunskapskrav som handlar om att eleverna ska utveckla sin kunskap om samhälle, kultur och olika levnadsvillkor i spanskspråkiga delar av världen. De sade också att det innehåll i moderna språk (Skolverket, 20II) som handlar om att kunna söka och värdera olika typer av källor, till exempel från internet, borde passa in i ett temaarbete. Vidare önskade de att eleverna skulle utveckla sitt ordförråd och få träna vidare på att använda de konjunktivformer som de nyligen lärt sig.

Förutom ett tidigare ämnesövergripande rollspel om mänskliga rättigheter hade gruppen förberetts under ett par veckor. De hade till exempel arbetat med två textbokstexter med fokus på Latinamerika och mänskliga rättigheter. Eleverna hade också lyssnat på en del musik från Latinamerika och utifrån sångtexterna diskuterat de mänskliga rättigheterna. Därefter delade läraren in eleverna i grupper som efter att ha arbetat med det förestående temat under hela eller delar av I 6 lektioner skulle presentera ett eget valt latinamerikanskt land för klassen. Lärarna sade att eleverna nu äntligen skulle få mycket tid att på djupet bearbeta autentiskt material. För att temaarbetet skulle kunna knytas till 
styrdokumenten bestämde lärarna några obligatoriska rubriker om landet ifråga som skulle ingå i elevgruppernas slutliga presentationer: generell information om det eget valda landet, något om dess historia, något om mänskliga rättigheter och något om en berömd person från landet. Under temaarbetet behövde eleverna också skriva ett individuellt fiktivt brev till en kompis för att övertyga denna om att följa med på en resa till landet ifråga. Läraren introducerade arbetet genom att visa en digital presentation och avslutade med att visa en lista med länkar som hörde till varje land där kollegorna kontrollerat innehåll och språk i förväg. Eleverna upplystes om att de förväntades använda listan. Länkarna var organiserade efter de obligatoriska rubriker som skulle ingå i presentationen.

\section{Datainsamling och analysmetod}

Datainsamlingen genomfördes på en kommunal mellanstor storstadsskola där eleverna ofta arbetar med tema. Alla elever har utrustats med egen dator som de förväntas ta med sig vid varje lektion. Lärarna har gått flera fortbildningar om hur datorer kan användas i utbildning och skolans arkitektur planerades redan från start med tanke på elevdatorerna - till exempel finns datorladdare i varje elevskåp och många små grupprum i anslutning till klassrummen där eleverna förväntas kunna arbeta stor del av sin tid i skolan. För att läsaren ska kunna förstå avhandlingens resultat behöver studiens deltagare och de sätt på vilka data samlades in nämnas åtminstone kortfattat. För en djupare förståelse inför hur begränsningar i urval och metod påverkat studiens resultat hänvisas till studien i fullo (Källermark Haya, 20 I 5 a).

Primärdata till studien samlades in under tre planeringsmöten mellan läraren Sara och hennes ämneskollegor under vårterminen 20I3, under den första lektionen i temat samt i efterföljande semistrukturerade intervjuer med eleverna och Sara. Under lektionen spelades två grupper med tre elever i varje in under 80 minuter. För att kunna analysera tillfället i detalj användes skärminspelningar från de sex elevernas datorer, samt ljud- och filminspelningar. På det sättet kunde jag sedan se till exempel hur eleverna rörde sig samtidigt som de sa något och vad de skrev $\mathrm{i}$ sina anteckningar på datorn, vilken sida som var aktiv på deras 
dator just då och vem de vände skärmen emot. Under de efterföljande intervjuerna tittade varje elev och jag på skärmfilmen tillsammans och eleven uppmanades att trycka på paus om det fanns något att reagera på. I den senare intervjun med läraren användes kollegornas gemensamma planeringsdokument och lärarens introducerande digitala presentation som stöd för minnet.

Elevintervjuerna transkriberades och kategoriserades i protokoll som visade simultana händelser för respektive elev, sekund för sekund. Protokollen använde kategorierna tid, websida, språk, antal öppna flikar, vad som hände på skärmen, tal, gester och kroppens position. De två sista kategorierna sållades bort före analysen eftersom de aldrig nämndes av eleverna i intervjun som betydelsefulla resurser.

Ordningen i vilken kategorierna analyserades styrde med säkerhet också vad jag som forskare lade märke till. Först sågs skärmfilmerna flera gånger både med ljud och utan. Sedan lyssnades konversationerna igenom: först utan bild, sedan tillsammans med video och till slut även tillsammans med skärmfilmerna.

För att kunna sätta in ovanstående val och handlingar i ett större sammanhang utnyttjades Engeströms modell för aktivitetsteori (Engeström, I987, 2000, 200I). Denna gjorde det möjligt att analysera hur både läraren och elevgrupperna uttryckte sig om temaarbetets resurser, arbetsregler, mål, gruppsammanhang och arbetsfördelning. Inte minst kunde dessa scheman synliggöra det mellanrum där lärares och elevers aktivitetssystem blandades eller inte stämde överens, och där spänningar och konflikt uppstod.

\section{Resurser som valdes och som synliggjordes med hjälp av intervjuerna}

De sammanfattade resultaten som följer har valts ut för att synliggöra diskrepansen mellan lärares och elevers aktivitetssystem. För mer detaljerade och utförliga resultat hänvisas återigen till studien i sin helhet.

I lärarintervjun uttrycktes följande viktiga resurser för elevgrupperna: läraren, målspråket, arbetsgrupperna, det virtuella kursrummet, elevernas valfrihet, att eleverna hade mycket tid på sig, de förberedande lektionerna, olika media som exempelvis musik och lärarens digitala presentation. Hon sade att det nog 
hade varit lätt för eleverna att hitta informationen de behövde, eftersom de var så vana vid att söka information på internet.

Eleverna svarade å sin sida, att Wikipedia blev en av de viktigaste resurserna för dem, samtidigt som de tvivlade på källans kvalitet. De nämnde som positivt när de kände till källans kvalitet, vilket de sa att de inte gjorde med de spanska källorna som lärarna bett dem använda. Två av sex elever berättade att de såg det som viktigt att endast använda sökord på spanska. Eleverna nämnde också som resurser Google Translate (hädanefter GT) - som de berättade att de blivit ombedda av läraren att inte använda - och Lingro.com, en websida som översätter enstaka ord från spanska till engelska ur spanska texter när man håller musmarkören stilla över det aktuella ordet.

Även Google Search och det gemensamma Google Docsdokumentet där eleverna valde att gemensamt samla information omnämndes av de flesta. Eleverna sade att arbetet blev lättare när alla kunde samla information på samma ställe och nämnde också tiden som en viktig resurs. De påpekade att det tog mycket längre tid att söka information på spanska än på engelska eftersom de på spanska behövde läsa varje individuellt ord. Två elever berättade att de filtrerade sina sökningar mycket mindre på spanska än på engelska, och att de var mer benägna att bara välja de sidor som dök upp först. Eleverna upplyste dessutom om att det inte bara var svårt att hitta och välja information, utan även att välja vad de skulle skriva om.

Grupperna framhöll att det positiva med att söka efter information som en del av språkstudierna framför allt var att det var intressant att lära sig om andra länder och att läsa autentisk text. Dessutom sade de att autonomin i arbetssättet gjorde det lättare att lära sig än om de bara tvingades lyssna på läraren. Eleverna framhöll som negativt att det tog väldigt lång tid att lära sig mycket lite spanska.

\section{Resurser som valdes och som synliggjordes med hjälp av observationerna}

De resurser som analyserades, förutom de som framkom genom intervjuerna, var de som observerades av forskaren i transkriptionerna. 
Dessa resurser utgjordes av: elevernas arbetsgrupp och det gruppen pratade om, det av arbetsgruppen delade arbetsdokumentet, olika webbsidor, lärarens digitala presentation som låg i ett virtuellt kursrum, bilder på webben, layout och olika språk.

Cirka en tredjedel av gruppernas arbetstid användes till samtal på svenska. Dessa samtal innehöll först och främst frågor till gruppen om formatering, vad uppgiften egentligen innehöll, hur mycket gruppen förväntades göra och hur arbetet kunde fördelas mellan gruppmedlemmarna. Vidare diskuterades innebörden av begreppet autentisk text, och vilken sorts information som egentligen var värdefull nog att ta med. Kommentarer som: Gud, vad vill vi veta om DET HÄR? förekom vid flera tillfällen (Källermark Haya, 20 I 5a, s. I37). Spanska ord eller fraser, liksom grammatiska spörsmål, diskuterades vid enstaka tillfällen.

Eleverna spenderade mellan 5-I 8 minuter (av de 3 I som arbetstiden i grupprummet bestod av) i deras gemensamma arbetsdokument på internet (Google Drive). Båda grupperna öppnade ett sådant så fort någon av medlemmarna fått nätaccess och alla tog det för självklart att det var på det sättet de skulle arbeta. De var helt enkelt vana vid det sedan tidigare - både från andra lektioner och från när de arbetade tillsammans i spanska.

Gruppens medlemmar kunde skriva på olika ställen i dokumentet samtidigt och på samma gång se vad de andra gruppmedlemmarna gjorde i det. De infogade kommentarer till sig själva och de andra i marginalen. Någon skrev på svenska eller klistrade in information på engelska, en annan skrev av information från lärarens digitala presentation eller klistrade in ord och meningar som tidigare skrivits på svenska i ett anteckningsprogram och sedan översatts med hjälp av GT. En tredje skrev egna meningar direkt på spanska. Ytterligare en elev sysslade med översättningar till spanska från ett tidigare arbete på svenska. Hon hade ställt in spanska som språk i sin dator och använde därmed den spanska grammatik- och stavningskontrollen. Alla lade också tid på att skriva rubriker till olika stycken och att formatera text och punktlistor.

Vad det gällde de websidor som var språkligt inriktade så användes GT mellan en och I 3 gånger, och fem av sex elever använde den. Lingro.com användes av två elever. On-line lexikon användes 
vid ett tillfälle, av en elev. Wikipedia användes på svenska, engelska och spanska. Fem av sex hade sparat det virtuella kursrummet som favorit och där fanns lärarens digitala presentation. Både i rummet och i presentationen var allt skrivet på spanska. De obligatoriska rubrikerna från lärarens presentation kopierades tidigt in i arbetsdokumenten och användes som en strukturerande resurs. Övriga websidor var Google Search och Google Drive. Två länkar från lärarens lista användes vid ett enstaka tillfälle, av en elev.

Copy/paste var den resurs som användes av alla. Mest klistrades information in på svenska, sedan på engelska och minst på spanska. Nästan all information i det gemensamma dokumentet var inklistrad eller avskriven (förutom rubrikerna).

En resurs utgjordes av Drive-dokumentet som anteckningsverktyg och där skrevs även kommentarsfält i marginalen. En elev använde ett program gjort för anteckningar, som möjliggjorde att hon skrev samtidigt som hon läste på någon annan aktuell sida, vilket gjorde att hon inte behövde bläddra mellan olika fönster. Vad gällde flikar som resurs, höll eleverna mellan ıo och I 7 flikar parallellt öppna och rörde sig mellan dem.

Övriga resurser som både observerades av forskaren och omnämndes av eleverna var tid, layout, bild och språk. Vad gäller tiden, utförde eleverna många handlingar på kort tid. De nämnde för varandra under arbetets gång att de hade ovanligt mycket tid att slutföra arbetet på men att arbetet gick långsamt. Layouten rörde formatering av rubriker och listor, typsnitt och att formatera om hypertext så att det såg ut som vanlig text. Vad gäller bilder som resurs, navigerade eleverna mellan bildbanker, Prezi-presentationer som byggde på bilder, pop-up reklam från Venezuela och en kort film om historia. Av detta syntes dock ingenting $\mathrm{i}$ arbetsdokumentet vid lektionens slut.

Eleverna använde mest svenska emellan sig som språklig muntlig resurs, förutom vid översättning av vissa ord eller när eleverna skulle förklara skillnaden mellan tempus för varandra. När problem uppstod angående betydelsen av vissa lästa ord så gällde det ofta ord från lärarens digitala presentation. Både när det gällde språk som lästes på webben och vad som användes skriftligt i 
arbetsdokumentet var det engelska i första hand, i andra hand svenska och i tredje hand spanska som användes.

\section{Diskussion av studiens resultat}

Resultaten synliggör en del spänningar. Till exempel så koncentrerar sig eleverna i tal och handling på att arbetet ska gå snabbt och leda till en slutprodukt, dvs. presentationen för gruppen, snarare än att fokusera på den egna lärprocessen som pågår under tiden. Grupperna berättade till exempel att de genom grupparbetespedagogiken nog inte lärde sig mera än om de hade arbetat med kursinnehållet på ett mer enligt dem traditionellt sätt, men att de kunde slutföra arbetet snabbare än genom att arbeta ensamma. Detta trots att lärarna ursprungligen designade uppgiften för att eleverna skulle kunna ta lång tid på sig att verkligen försöka penetrera autentisk (och därmed svår) text.

Eleverna uttryckte att det var roligt att arbeta i grupp och i tema, eftersom det fick dem att känna sig produktiva. Att det var roligt ökade också deras motivation. De sade också att de hade roligt under lektionen och de uttryckte själva att de arbetade ovanligt effektivt. De framhöll att de arbetade på uppgiften hela tiden men även att de inte upplevde att de lärde sig någon spanska; att det språkligt sett var svårt och att det genom att arbeta såhär tog väldigt lång tid att lära sig väldigt lite spanska. Samtidigt som de alltså faktiskt utförde många olika handlingar på kort tid ansåg de att de tvingades arbeta ovanligt långsamt eftersom arbetet var på spanska. När eleverna säger "produktivt" tycks de med andra ord mena att de gjorde många saker tillsammans på kort tid snarare än att de använde och lärde sig spanska.

I början av texten nämndes tanken att språkinlärning i hög grad "går till i förhållande till, tillsammans och genom andra" (Svensson, 2008, s. 58.) Svensson skriver vidare om att den digitala tekniken kan fungera motiverande när den är social. Vad det gäller den spanska språkinlärningen och vad gruppen samtalade om i det här arbetet kan man dock diskutera om elevernas arbete var socialt och huruvida det stödde språkinlärningen. Under arbetspasset fördes gruppens konversationer på svenska utom 
vid enstaka ord, och rörde mest administrativa spörsmål samt vad som ansågs värt att ta med i presentationen, snarare än att tillsammans försöka förstå något nytt eller använda och därmed befästa något tidigare förvärvade kunskaper i spanska. Spanska var också det språk som för fyra av sex elever var minst representerat bland de olika informationssökningarna och bland sidorna som användes.

Ett ytterligare spänningsområde som studien tydliggör är elevernas bruk av copy/paste. Trots att eleverna sade att de såg copy/ paste och GT som användbara resurser så uttrycker de samtidigt att de känner sig konfliktfyllda inför sin användning av dem. En orsak till detta skulle kunna ligga i det Benyamine (2008) skrev om, som handlade om att lärmaterialet i samband med internet ofta blir abstrakt och opersonligt snarare än konkret och möjligt att relatera till. Till exempel, snarare än att bygga sina egna meningar i det gemensamma arbetsdokumentet utifrån nyckelord eller koncept de hittar, så klistrar eleverna in ord och meningar från texterna de hittar på internet utan att alls reflektera över språket i dem.

Det finns två olika sorters situationer där copy/paste används av eleverna i studien. Den första är när ren ämnesinformation kopieras in i arbetsdokumentet. Den andra är när eleverna klistrar in ord eller meningar i GT för att få hjälp med lingvistiska problem. I den här situationen uttrycker alla utom en att det på något sätt känns konfliktfyllt, att de egentligen vet att det inte är bra. En flicka lovprisar däremot denna funktion, eftersom hon känner att hon genom detta kan få hjälp med att uttrycka komplicerade saker som hon annars inte skulle kunna. Alla elever påpekar att de är medvetna om att GT översätter fel och de löser detta genom att till exempel jämföra översättningar mellan olika språk eller fråga varandra.

Ytterligare spänningsområden uppstår när eleverna gör skola (Pope, 200I; Selwyn, 20I I) i och med att de tolkar situationen som att det är själva insamlandet av information och skapandet av en presentation som läraren tycker är viktiga, snarare än att de ska arbeta med något som de själva är intresserade av, och ta sig tid till något de upplever som svårt. Denna elevtolkning styr i sin tur handlingarna i elevernas aktivitetssystem. Det aktivitetssystem 
inom vilket eleverna arbetar strukturerar deras användning av digitala verktyg och hur de kommunicerar. Med andra ord handlar lektionens innehåll för dem om snabbhet, bullet-points och den slutliga digitala presentationen. Detta fokus riktar också sättet på vilket eleverna lär sig. Häri finns en konflikt mellan elevernas och lärarens aktivitetssystem. Dessutom arbetar eleverna individuellt trots att deras gemensamma digitala skrivdokument tillåter samarbete. Detta medför att nästan inga diskussioner förs om vare sig ämnesinnehåll eller språkliga problem.

Det sista resultatområdet att diskutera i det här kapitlet rör det faktum att eleverna arbetar med flera saker på samma gång. Exempelvis kan elever samtidigt som de läser ha en eller flera flikar öppna där de skriver samtidigt som de andra i gruppen. Samtidigt som de försöker förstå viss information så presenterar de den för de andra i sin grupp genom att klistra in den i det gemensamma arbetsdokumentet. Detta märks till exempel när de använder sitt gemensamma Google Docs-dokument, GT eller copy/paste.

\section{Implikationer för språkundervisningen}

Vilken didaktisk betydelse kan diskrepansen mellan elevernas och lärarnas aktivitetssystem ha för vad som blir viktigt i svensk språkundervisning när digitala verktyg och informationssökning blir en del av språkundervisningen?

För det första bör vi eventuellt komplettera vår syn på språkinlärningens färdigheter. Lärare beskriver ofta språk som färdigheter som är antingen receptiva, produktiva eller interaktionella. Denna språksyn går ofta igen i både test och övningsuppgifter. Men till vilket färdighetsfack - det receptiva, produktiva eller interaktionella, hör att informationsbearbeta? Eftersom elever, när de lär sig språk, skapar ett eget språk för att möta sina kommunikativa behov (Lantolf \& Thorne, 2006, s. 9) så kan det uppstå ett validitetsproblem när elever som en del av sitt lärande, och för att utföra uppgifter, behöver använda språket på ett sätt som inte läraren inte nödvändigtvis ser som en språkfärdighet bland andra. Men genom att synliggöra fler aspekter av vad en färdighet innehåller så kan elevernas lärandespråk (Ortega, 20I3), och med det själva lärandeprocessen, synliggöras. Det handlar om att 
se processen bakom slutprodukten. Med en kompletterad syn på språkinlärning följer att elevernas uppgifter kan behöva kompletteras. Till exempel skulle det då kunna bli just arbetsprocessen $i$ sig som blir intressant för läraren att eleverna redovisar. I linje med denna breda språksyn använder Europarådet mediering som en färdighet, och beskriver så kallade 'mediation activities' i kompletteringen till Common European Framework of Reference for Languages: Learning, Teaching, Assessment, Europarådets gemensamma referensram för språk (Council of Europé, 200I, Council of Europe/Skolverket, 2009), the Companion volume (Council of Europe, 20I 8).

Studiens resultat aktualiserar dessutom en didaktisk diskussion om elevernas hjälp och scaffolding (stöttning). Att använda informationssökning på internet som en del av att lära sig ett främmande språk kan i bästa fall hjälpa till att öka motivationen, elevernas autonomi, kritiska reflektioner och organisatoriska färdigheter samtidigt som det ger läraren möjlighet att effektivt stötta en individualiserad läroprocess (Alstedter \& Jones, 2009).

Icke desto mindre: vid den muntliga presentationen av ett tema syns inte nödvändigtvis om eleven valt att arbeta genom att först läsa på svenska eller engelska för att sedan översätta sin presentation till spanska, eller om eleverna lyckats läsa på spanska direkt för att sedan plocka ut nyckelorden till sin presentation. Vad det är individerna faktiskt gjort och lärt sig under vägen är radikalt olika, och de respektive lärandesätten kräver sin egen form av stöttning. Här blir lärarens roll extremt viktig. Detta kan jämföras med att Vigmo (2010) fann att elever som arbetar i grupp helst vänder sig till varandra, och inte till läraren, för hjälp.

Min studies resultat leder till en diskussion om prioriteringar i undervisningen. De styrdokument lärare och elever har att förhålla sig till innehåller ett brett centralt innehåll och mycket skall hinnas med på få timmar. Är då Google Translate-användning, delade skrivdokument och copy/paste det som tiden bör användas till? Blir inte kunskaperna för ytliga? Bör möjligheten att låta eleverna få arbeta på sätt de troligtvis är vana vid hemifrån eller möjligtvis från studierna i engelska rymmas även inom spanskundervisningen eller ska lektionerna i spanska stå för något annat slags innehåll? Vad är det egentligen eleverna övar på och lär sig 
i ett temaarbete som det ovan - är det både administrativa, mer ytliga kunskaper eller kunskaper av mer resonerande karaktär, och förståelse av språkliga problem?

Dessa frågor skulle kunna inleda ett samtal om vad språklärare erkänner som legitimt kunskapsstoff när nybörjare eller elever på grundläggande nivå ska skaffa information på spanska på internet och sedan presentera det de lärt sig? Som svar på en artikel (Levi Altstaedter \& Jones, 2009) där författarna undersökte elevers ökade motivation när de inom ramen för språkstudierna sökte information på webben, ifrågasatte Ping Wu (2010) om informationssökning och kulturella kunskaper inte bör utgöra helt egna kurser? Hon menade att de inte alls bör rymmas inom språkkurser för nybörjare (Wu, 20Iо). Man kan dock argumentera för att de bör det. Enligt gymnasieskolans läroplan är det skolans ansvar att eleven "kan använda bok- och bibliotekskunskap och modern teknik som ett verktyg för kunskapssökande, kommunikation, skapande och lärande (Lgy I I:9). Språkundervisningen bör också bidra till detta. Vi använder språk på det sättet. Vår förmåga att sammanställa information från olika webbsidor och blanda texter dagligen utgör numera ett sätt för oss att kommunicera på och därmed har dessa kunskaper att göra med vår förmåga att lära oss språk. Med detta sagt behöver vi naturligtvis problematisera hur vi bäst inkluderar dessa delar i språkkurserna snarare än att exkludera dem helt.

Vi behöver som språklärare (och elever!) kontinuerligt fråga oss med vilket syfte språket lärs in och vems det syftet är. Eleverna i den här studien visar genom sina val, handlingar och uttalanden att deras tolkning av detta är att koda av vad de tror att läraren vill att de ska ta med i den slutliga presentationen. Syftet med deras arbete blir då att framföra en digital presentation på spanska för sina kamrater. Däremot övar de på en hel del annat under sin faktiska lärandeprocess: även om de inte pratar mycket med varandra på eller om spanska så kommunicerar de med varandra i ett gemensamt arbetsdokument, hjälper varandra att tolka instruktioner och webbsidor på olika språk, de undervisar varandra i hur de kan använda olika verktyg och navigera bland olika siter (bland annat i sitt virtuella kursrum), hur de kan söka på webben med spanska nyckelord eller använda presentationer 
på nätet för att hitta den information de behöver. Dessa kunskaper $\mathrm{i}$ informationsbearbetning syns inte alls i efterhand för läraren.

Min studie pekar bland annat mot följande didaktiska frågor att arbeta vidare med:

- Vad i språkundervisningen vill vi att eleverna skall använda datorer till och i vilket syfte? Vilket skulle kunna bli lärarnas aktivitetssystem i den situationen och i hur stor grad skulle elevernas skilja sig från det?

- Speciellt med tanke på arbetet med digitala resurser i språkklassrummet: vilka problem och vilka möjligheter ser vi med att tydligare synliggöra språk som lärandeprocess snarare än slutprodukt och hur skulle det kunna åstadkommas?

- Vilka problem respektive möjligheter ser vi med att använda internet i språkundervisningen vad det gäller begreppen copy/paste, producent/konsument, och bredd respektive djup i lärandet?

Att kunna frikoppla sig från hantverket i klassrummet för att kritiskt kunna reflektera över sitt eget arbete är svårt. Ett stöd för att kunna göra det är att läraren tänker i termer av att försöka synliggöra olika mål och aktivitetssystem, för att kunna minska glappet mellan de egna och elevernas.

\section{Referenser}

Benyamine, I. (2008). Digitalt berättande och identitet. I A. Rostvall, \& S. Selander (Red.), Design för lärande (s. 195-202). Norstedts Akademiska Förlag.

Conole, G. (2008). Listening to the learner voice: the ever changing landscape of technology use for language students. ReCALL, 20, I 24-I4O. http://dx.doi.org.proxy.kib.ki.se/IO.IOI7/So95 8344008 000220

Council of Europe (200I). Common European Framework of Reference for Languages: Learning, Teaching, Assessment. http:// www.coe.int/t/dg $4 /$ education/elp/elp-reg/cefr_EN.asp

Council of Europe/Skolverket (2009). Gemensam europeisk referensram för språk: lärande, undervisning och bedömning. Skolverket. 
https:/www.skolverket.se/skolutveckling/inspiration-och-stod-i -arbetet/stod-i-arbetet/gemensam-europeisk-referensram-for -sprak-gers

Council of Europe (2018). Common European framework of reference for languages: Learning, teaching, assessment. Companion volume with new descriptors. Language Policy Programme. Education Policy Division. Education Department. Council of Europe. https://rm.coe.int/cefr-companion-volume-with -new-descriptors-20I 8/I680787989

Diaz, P. (201 2). Webben i undervisningen: digitala verktyg och sociala medier för lärande. Studentlitteratur.

Engeström, Y. (1987). Learning by expanding. Orienta-Konsultit.

Engeström, Y. (2000). Activity theory as a framework for analyzing and redesigning work. Ergonomics, 43, 960-974. https://doi.org /IO.IO80/OOI40I300409I43

Engeström, Y. (200I). Expansive learning at work: toward an activity theoretical reconceptualization. Journal of Education and work, I4, I33-I 56. https://doi.org/IO.IO80/I3639080020028747

Fredholm, K. (2015). Eleverna, datorn och språket. Studier av skoldatoriseringens effekter pà elevers attityder, skrivstrategier och textproduktion $i$ spanskundervisningen på gymnasiet [Licentiatuppsats, Stockholms universitet]. http://su.diva-portal.org /smash/record.jsf?pid=diva2 \% 3 A8 49604\&dswid=-5437

Grönlund, A. (20I4). Att förändra skolan med teknik. Bortom "en dator per elev". Örebro universitet. http://oru.diva-portal.org/smash /get/diva2:706366/fulltextor.pdf

Kress, G. (2009). What is mode? I C. Jewitt, G. Kress \& D. E. Mavers (Red.). The Routledge handbook of multimodal analysis (s. 54-67). London: Routledge.

Källermark Haya, L. (2015a). Agency in the Spanish language classroom. Student and teacher choices, actions and reports when students search for information online as part of a theme [Licentiatuppsats, Stockholms universitet].http://su.diva-portal.org /smash/record.jsf? pid=diva2\%3 A I 064287\&dswid=-6 I 7 I

Källermark Haya, L. (2015b). Scroll, copy and paste: students of Spanish searching for Information Online. Nordic Language 
Journal of Modern Language Methodology, 3, I48-167. https:// journal.uia.no/index.php/NJMLM/issue/view/56

Lantolf, J. P., \& Thorne, S. L. (2006). Sociocultural theory and the genesis of second language development. Oxford University Press.

Levi Altstaedter, L., \& Jones, B. (2009). Motivating students' foreign language and culture acquisition through web-based inquiry. Foreign Language Annals, 42, 640-657. https://doi.org/IO.I I I I /j.I944-9720.2009.01047.x

Ortega, L. (2013). SLA for the 2Ist century: disciplinary progress, transdisciplinary relevance, and the bi/multilingual turn. Language Learning, 63, I-24. https://doi.org/IO.I I I I/j.I467-9922.20I 2 $.00735 \cdot \mathrm{x}$

Patterson, N.G. (2000). Hypertext and the changing roles of readers. The English Journal, 90, 74-80. https://www.jstor.org/stable /82I22I

Prensky, M. (200I). Digital natives, digital immigrants part I. On the Horizon, 9, I-6. https://doi.org/IO.I I08/I0748 I 20 I I04248 I 6

Pope, D.C. (200I). Doing school: how we are creating a generation of stressed out, materialistic, and miseducated students. Yale University Press.

Samuelsson, U. (20I4). Digital (o)jämlikhet? IKT-användning $i$ skolan och elevers tekniska kapital. School of Education and Communication. http://hj.diva-portal.org/smash/record.jsf?pid $=\operatorname{diva2} \% 3$ A68 I $386 \&$ dswid $=7840$

Selwyn, N., Potter, J. \& Cranmer, S. (2010). Primary schools and ICT: learning from pupil perspectives. Continuum.

Selwyn, N. (201 I). Schools and schooling in the digital age. A critical analysis. Routledge.

Skolverket (20II). Läroplan för moderna språk 4. https://www.skolv erket.se/undervisning/gymnasieskolan/laroplan-program-och -amnen-i-gymnasieskolan/gymnasieprogrammen/amne? url = I 5303 I 473 I \% 2Fsyllabuscw \% 2Fjsp \% 2Fsubject.htm \% ${ }_{3}$ FsubjectCode $\%_{3}$ DMOD \% 26 courseCode $\%_{3}$ DMODXXX ${ }_{4} \%{ }_{2}$ 6tos $\%_{3}$ Dgy\&sv.url =I 2.5 dfee 447 I 5 d 35 a 5 cdfa92a 3 \#anchor_MODXXXo4 
Skolverket (2016). IT-användning och IT-kompetens i skolan. Skolverkets it-uppföljning 20I5. http://www.skolverket.se/publikationer?id $=36 \mathrm{I} 7$

Svensson, P. (2008). Språkutbildning i en digital värld - informationsteknik, kommunikation och lärande. Norstedts Akademiska förlag.

Vaca Uribe, J. \& Hernández, D. (2006). Textos en papel vs. textos electrónicos: ¿nuevas lecturas? Perfiles educativos, 28, 106-I 28. https://www.researchgate.net/publication/40428032_Textos_en _papel_vs_textos_electronicos_nuevas_lecturas

Vigmo, S. (2010). New spaces for language learning. A study of student interaction in media production in English [Doktorsavhandling, Göteborgs universitet]. http://hdl.handle.net/2077/22256

Wu, P. (2010). The National standards for foreign language learning: Where's the beef? A response to “Motivating Students' Foreign Language and Culture Acquisition through Web-Based Inquiry" by Levi Altstaedter \& Jones. Foreign Language Annals, 43, 559-62. https://doi.org/IO.I I I I/j.I944-9720.20IO.O I I I 2.X 